\title{
Protein phosphorylation in Escherichia coli L. form NC-7
}

\author{
P. Freestone, ${ }^{1}$ S. Grant, ${ }^{1}$ M. Trinei, ${ }^{1}$ T. Onoda ${ }^{2}$ and V. Norris ${ }^{3}$ \\ Author for correspondence: V. Norris. Tel: +3323514 6908. Fax: +33 235147020 . \\ e-mail: vjn@univ-rouen.fr
}

\footnotetext{
1 Department of Microbiology and Immunology, Medical Sciences Building, University of Leicester, Leicester LE1 9HN, UK

2 Department of Biology, Faculty of Science, Shimane University, Matsue 690, Japan

3 IFR 'Systèmes Intégrés', Laboratoire de

Microbiologie, Faculté des Sciences et Techniques de Rouen, F76821 Mont Saint Aignan, France
}

\begin{abstract}
Wall-less L-forms of Escherichia coli constitute an interesting, and relatively underused, model system for numerous studies of bacterial physiology including the cell cycle, intracellular structure and protein phosphorylation. Total extracts of the L-form revealed a pattern of protein phosphorylation similar to that of an enteropathogenic strain but very different from its parental K-12 strain. In particular, the L-form extract revealed phosphorylation on tyrosine of a protein important in pathogenesis, TypA, and calcium-specific phosphorylation of a $40 \mathrm{kDa}$ protein. Two new phosphoproteins were identified in the L-form as the DNA-binding protein Dps, and YfiD, a protein of $14 \mathrm{kDa}$ with homology to pyruvate formate-lyase and a region containing a tRNA cluster in bacteriophage T5.
\end{abstract}

Keywords: Dps, YfiD, TypA, tyrosine phosphorylation, calcium

\section{INTRODUCTION}

L-forms are bacteria that have lost their ability to construct cell walls and, bounded only by a cytoplasmic membrane, are particularly fragile. There appear to be two classes of L-forms. Unstable L-forms regain the ability to construct their walls and revert readily to a bacterium resembling the parental strain whilst stable Lforms have almost lost this ability and revert much less readily. Both stable and unstable L-forms have been obtained by independent workers from many bacteria including Escherichia coli (Gumpert, 1992; Lederberg \& St Clair, 1958; Onoda \& Oshima, 1988; Paton, 1987; Waterhouse et al., 1996). E. coli L-forms should be particularly interesting for studies of bacterial physiology since they combine the advantages of, firstly, the E. coli model system with its well-explored genetics, secondly, a structure in which the peptidoglycan sacculus is absent and the cytoplasmic membrane is exposed, and, thirdly, an extreme fragility which allows the rapid extraction of labile enzymes.

L-forms remain intact, grow, segregate their chromosomes and divide because they possess an intracellular structure that can serve as an alternative to peptidoglycan in the particular conditions in which they grow. In normal cells, intracellular structure may be conferred by self-associating enzymes (Mendes et al., 1995; Srere,

Abbreviation: TPA, 12-tetradecanoylphorbol 13-acetate.
1987) and a 'solid-state' metabolism (Ingber, 1993) that may exist as an 'enzoskeleton' (Norris et al., 1996). In Lforms, the elements of such an enzoskeleton might be expected to be up-regulated and evident candidates include FtsZ, a protein with some similarity to tubulin that assembles into a 'contractile ring' at the start of cell division (Bi \& Lutkenhaus, 1991; Ma et al., 1996), Dps, a principal component of 'actomyosin' preparations of E. coli (Foster, 1993) which is induced to protect DNA from oxidative damage (Almiron et al., 1992), and elongation factor EF-Tu, which has actin-like properties (Weiser et al., 1982; Guerrero-Barrera et al., 1996).

It is conceivable that a bacterial enzoskeleton would be regulated, like its eukaryotic equivalent, by eukaryoticlike kinase activities that phosphorylate proteins on serine, threonine and tyrosine residues (STY phosphorylation) or by the 'two-component' kinases that phosphorylate on histidine (Saier, 1993). In E. coli, STY-phosphorylated proteins make up the majority of the 130 proteins phosphorylated in vivo (Cortay et al., 1986a). A number of these proteins have now been identified (for references see Kennelly \& Potts, 1996) and include elongation factor Tu (Lippmann et al., 1993), heat-shock protein DnaK (Cegielska \& Georgopoulos, 1989; McCarthy \& Walker, 1991; Sherman \& Goldberg, 1993), a Ras-like protein, Era (Sood et al., 1994), the Universal Stress Protein, UspA (Freestone et al., 1997), and possibly the cell division protein FtsA (Sanchez et al., 1994). Using an in vitro assay (Norris et 
al., 1991), we have identified several other phosphoproteins including ribosomal protein $\mathrm{S} 1$, succinyl-CoA synthetase and TypA (Freestone et al., 1995; Sweeney et al., 1995), which appears to be a new class of virulence regulator (Farris et al., 1998) and which interacts with global regulators such as $\mathrm{H}-\mathrm{NS}$ and UspA (Freestone et al., 1998). In these studies, difficulties were often encountered due to the lability of the kinase activities and the multiplicity of interacting factors. Here, we study protein phosphorylation in L-form extracts and identify phosphoproteins that may be involved in Lform structure.

\section{METHODS}

Bacteria and growth conditions. L-form NC-7, parental strain 3301 (Onoda et al., 1987) and enteropathogenic strain MAR001 (Baldini et al., 1983) were used in this study. The Lform and strain 3301 were grown without agitation in $200 \mathrm{ml}$ of a $1 \mathrm{l}$ solution containing $10 \mathrm{~g}$ peptone, $5 \mathrm{~g}$ yeast extract, $2 \mathrm{~g}$ glucose and $19.8 \mathrm{~g} \mathrm{NaCl}$ at $30^{\circ} \mathrm{C}$ for $2 \mathrm{~d}$ (to $\mathrm{OD}_{600} 0.5-0.7$ for the L-form and to $\mathrm{OD}_{600} 2.4$ for strain 3301 ; measured with a Philips PU 8720 UV/VIS Scanning spectrophotometer), as described previously (Onoda et al., 1992). Strain 3301 and other bacteria were also grown aerobically at $37^{\circ} \mathrm{C}$ in the same medium to an $\mathrm{OD}_{600}$ of 1 (Freestone et al., 1995).

Preparation of extracts and Mono Q 5/5 fractionation. Lforms were harvested by centrifugation at $2000 \mathrm{~g}$, washed in $20 \mathrm{mM}$ Tris/HCl, $1 \mathrm{mM}$ EDTA, $1 \mathrm{mM}$ DTT (TED buffer) containing $0.34 \mathrm{M} \mathrm{NaCl}$, and centrifuged again. The L-form cell pellet was resuspended in $10 \mathrm{ml}$ TED buffer containing protease inhibitors (chymostatin, leupeptin, pepstatin $\mathrm{A}$ and aprotinin at $1 \mu \mathrm{g} \mathrm{ml}^{-1}$ ) and sonicated for 5-10 s. Extracts from other bacteria were prepared as previously described (Freestone et al., 1995). Aliquots (25 mg) of whole extract were filtered $(0 \cdot 2 \mu \mathrm{m})$ and loaded onto a Pharmacia Mono $\mathrm{Q}$ $5 / 5$ column equilibrated in TED buffer as described previously (Freestone et al., 1995). Proteins were typically eluted at $1 \mathrm{ml} \mathrm{min}-1$ in $1 \mathrm{ml}$ fractions with a $25 \mathrm{ml}$ linear gradient of 0-600 $\mathrm{mM} \mathrm{NaCl}$. Protease inhibitors were added to all fractions (see above); these were stored at $-20^{\circ} \mathrm{C}$.

Kinase assays. Assays of total cell extracts and Mono $Q$ fractions (which contain autophosphorylating enzymes as well as co-eluting kinases and their substrates) were performed in $25 \mu \mathrm{l}$ volumes containing $20 \mathrm{mM}$ Tris $/ \mathrm{HCl}, \mathrm{pH} 7 \cdot 5,5 \mathrm{mM}$ $\mathrm{MgCl}_{2}$ and $0.185 \mathrm{MBq}\left[\gamma^{32} \mathrm{P}\right] \mathrm{ATP}$ (specific activity $1.10 \times 10^{8} \mathrm{MBq} \mathrm{mmol}^{-1}$ ) in $1 \mu \mathrm{M}$ cold ATP (minimal assay medium). Additions were made, where appropriate, of $1 \mathrm{mM}$ EGTA, $5 \mathrm{mM} \mathrm{CaCl}, 2.5 \mathrm{mM} \mathrm{MnSO}_{4}, 2.5 \mathrm{mM} \mathrm{ZnSO}$, $0 \cdot 10 \mu \mathrm{M}$ TPA (12-tetradecanoylphorbol 13-acetate) (in DMSO) and $40 \mu \mathrm{g} \mathrm{L}-\alpha$-phosphatidylserine $\mathrm{ml}^{-1}$. After $30 \mathrm{~min}$ incubation at $37^{\circ} \mathrm{C}$, the reactions were stopped by the addition of $25 \mu \mathrm{l}$ SDS-PAGE sample buffer, containing $10 \mathrm{mM}$ DTT. The samples were heated at $95^{\circ} \mathrm{C}$ for $5 \mathrm{~min}$, followed by SDSPAGE on appropriate percentage minigels. After electrophoresis, proteins were blotted onto PVDF membranes (Immobilon P; Millipore) at $0-4{ }^{\circ} \mathrm{C}$ in $25 \mathrm{mM}$ Tris, $192 \mathrm{mM}$ glycine, $0.037 \%(\mathrm{w} / \mathrm{v})$ SDS and $10 \%(\mathrm{v} / \mathrm{v})$ methanol. Blotted proteins were visualized with $0.1 \%$ Coomassie blue 250 in $50 \%$ methanol, followed by destaining with $50 \%$ methanol and $10 \%$ acetic acid. Autoradiography of the PVDF blots was carried out at $-70^{\circ} \mathrm{C}$ using Dupont Cronex X-ray film.

N-terminal sequencing. Chromatographically purified proteins (concentrated by lyophilization where necessary) were phosphorylated, separated by SDS-PAGE and electroblotted onto PVDF membranes, as described above. ${ }^{32} \mathrm{P}$ labelled protein bands were located by autoradiography, excised and the radioactive bands sequenced using an Applied Biosystems $470 \mathrm{~A}$ gas-phase sequencer. In each case, the $\mathrm{N}$ terminal sequence obtained corresponded to only one protein.

Residue stability analysis. PVDF membranes containing the ${ }^{32} \mathrm{P}$-labelled phosphoprotein were heated to either $90^{\circ} \mathrm{C}$ for $90 \mathrm{~min}$ in $16 \% \mathrm{TCA}$, to test for acid stability, or $60^{\circ} \mathrm{C}$ for $120 \mathrm{~min}$ in $1 \mathrm{M} \mathrm{KOH}$, to test for base stability. Membranes were neutralized, dried and reautoradiographed as described above.

Immunoblotting. For phosphotyrosine detection, proteins were separated on $10 \%$ SDS-polyacrylamide gels, transferred to PVDF membranes and probed with a 1:1000 dilution of anti-phosphotyrosine monoclonal antibodies (Sigma). Antibody recognition was detected using horseradish-peroxidaseconjugated secondary antibody and enhanced chemiluminescence (Amersham).

\section{RESULTS}

\section{Phosphorylation in total cell extracts}

The L-form and its parental strain are so different in morphology and rates of growth that comparisons, whilst informative, are not easy. Initially, both L-form

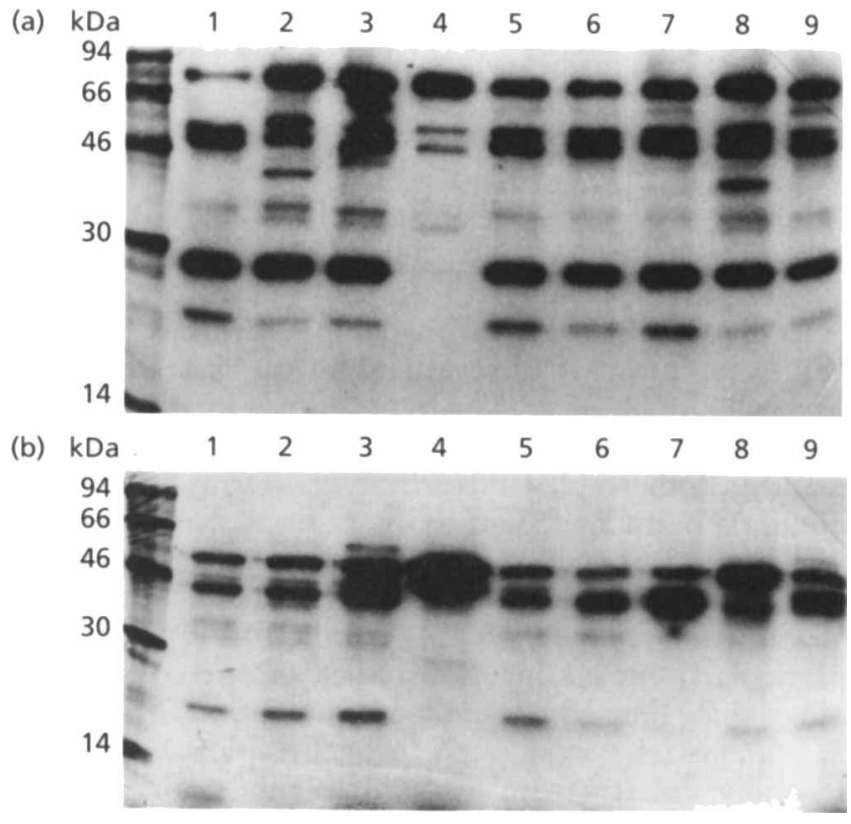

Fig. 1. ATP-dependent kinase activities in total extracts of (a) Lform and (b) parent. Extracts of L-form and parental strain 3301 , growing exponentially and harvested at $O D_{600} 0.7$ and 1 , respectively, were assayed (approximately $100 \mu \mathrm{g}$ protein) in minimal assay medium plus $1 \mathrm{mM}$ EGTA, as described in Methods, with the following additions. Lanes: 1 , no addition; $2,5 \mathrm{mM} \mathrm{CaCl}_{2} ; 3,2.5 \mathrm{mM} \mathrm{MnCl}_{2} ; 4,2.5 \mathrm{mM} \mathrm{ZnCl}_{2} ; 5,40 \mu \mathrm{g} \mathrm{L}-\alpha-$ phosphatidylserine $\mathrm{ml}^{-1} ; 6$, DMSO control $(10 \%) ; 7,0.1 \mu \mathrm{M}$ TPA in DMSO $(10 \%) ; 8,5 \mathrm{mM} \mathrm{CaCl}+0.1 \mu \mathrm{M}$ TPA in DMSO $(10 \%) ; 9$, $2.5 \mathrm{mM} \mathrm{ZnCl}+0.1 \mu \mathrm{M}$ TPA in DMSO $(10 \%)$. Proteins were separated by SDS-PAGE on $12 \%$ gels and transferred onto PVDF followed by autoradiography. 
and parent were harvested at similar optical densities whilst growing exponentially (and, in the latter case, aerobically) although we cannot exclude the possibility that 'exponential growth' of the L-form actually resembles stationary phase growth of the parent. After breaking cells carefully and rapidly to preserve possibly labile kinase activities, comparison of protein kinase activity in total extracts of the L-form and the parental strain revealed considerable differences (Fig. 1). In particular, proteins of 80 and $28 \mathrm{kDa}$ were strongly phosphorylated in the L-form but not in its parent whilst a calcium-specific phosphorylation of a $40 \mathrm{kDa}$ protein was also observed in the L-form but not in the parent (Fig. 1, lanes 2 and 8). Although addition of zinc inhibited the phosphorylation of several proteins in the $\mathrm{L}$-form, including those of 52,48 and $28 \mathrm{kDa}$, it stimulated specific phosphorylation of proteins of 52 and $48 \mathrm{kDa}$ in the parent (Fig. 1, lane 4). Finally, TPA had little effect on phosphorylation in the L-form but stimulated phosphorylation of proteins of 50 and $45 \mathrm{kDa}$ in the parent (Fig. 1, lanes 7 and 8).

\section{Phosphorylation in fractions}

To identify proteins phosphorylated in the L-form, anion-exchange chromatography (Mono $Q$ ) was used to generate fractions from the L-form. To facilitate comparisons between the L-form and its parent, the protein extracts used for fractionation were made from cells grown in L-form medium to similar optical densities (Fig. 2a, b) and from the parent grown as a stagnant culture for $2 \mathrm{~d}$ (Fig. 2c). As observed previously (Freestone et al., 1995), most proteins were eluted in the $100-500 \mathrm{mM}$ salt range. Although the pattern of phosphorylation in the L-form (using ATP as phosphate donor) varied with the age of the culture and with different experiments (data not shown), six prominent phosphoproteins were reproducibly observed of 80,70 , $65,36,32$ and $17 \mathrm{kDa}$ (Fig. 2a). With the exception of the $17 \mathrm{kDa}$ protein, these almost certainly correspond to those obtained from an enteropathogenic strain which include TypA (formerly o591, see below), DnaK, S1 and SucD (Freestone et al., 1995). This pattern of phosphorylation is different from that observed in fractions of laboratory strains such as the parental strain of the L-form (compare Fig. 2a with $b$ and c). For example, the phosphoproteins of 80 and $17 \mathrm{kDa}$ were absent from the fractions of the laboratory strains whilst a protein of $95 \mathrm{kDa}$ was present (Fig. 2b). The Nterminal sequence obtained for the $95 \mathrm{kDa}$ protein was SERFPNDVDPIE, which corresponds to residues 2-13 of the E1 component of the pyruvate dehydrogenase complex, a known phosphoprotein (Freestone et al., 1995). Synthesis of this enzyme is repressed in anaerobic growth and, not surprisingly, its phosphorylation was not detected in either the L-form (Fig. 2a) or the parental strain grown as a stagnant culture (Fig. 2c). The Universal Stress Protein, which is phosphorylated in vivo and in vitro (Freestone et al., 1997), was identified as a phosphoprotein (on the basis of antibody reactivity and phosphorylation characteristics) in the parent (a) $\mathrm{kDa}$

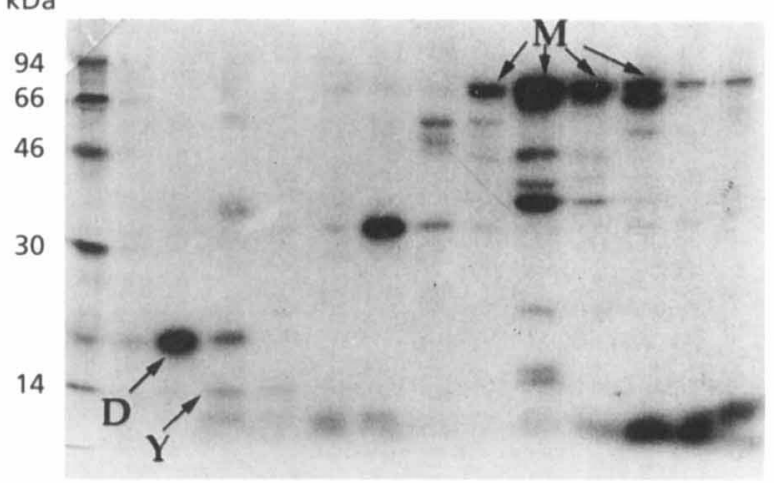

(b) $\mathrm{kDa}$

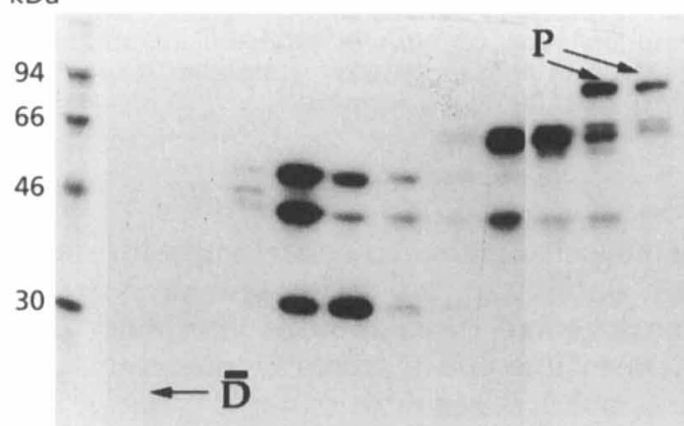

(c) $\mathrm{kDa}$

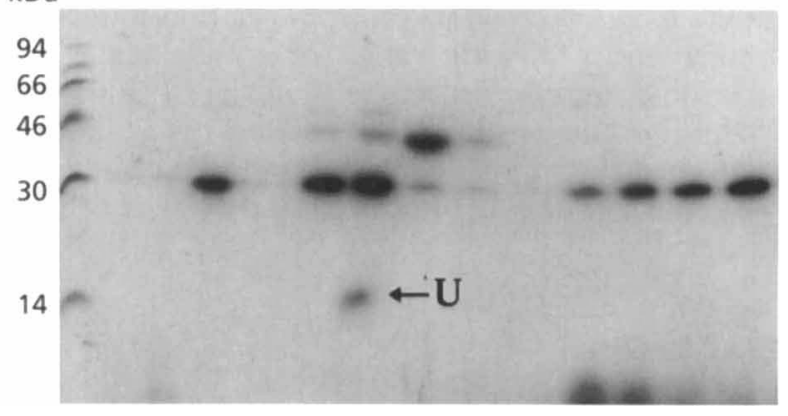

Fig. 2. ATP-dependent kinase activities in Mono $Q$ fractions of (a) L-form grown for $2 \mathrm{~d}$ as a stagnant culture to $\mathrm{OD}_{600} 0.7$, (b) parent grown aerobically to $\mathrm{OD}_{600} 0.7$ and (c) parent grown for $2 \mathrm{~d}$ as a stagnant culture to $O D_{600} 2 \cdot 4$. Extracts of L-form and parental strain 3301 were fractionated using Mono $Q$ anionexchange chromatography, as described in Methods. Samples $(20 \mu l)$ of fractions from the $100 \mathrm{mM}$ to $500 \mathrm{mM}$ region of the $\mathrm{NaCl}$ gradient were assayed in minimal assay medium plus $5 \mathrm{mM} \mathrm{CaCl} 2$ and $2.5 \mathrm{mM} \mathrm{MnCl}$ and phosphorylated proteins were analysed as in Fig. 1. $P$, Pyruvate dehydrogenase E1 subunit; M, TypA; D, Dps (D̄, Dps absent); U, UspA; Y, YfiD.

grown as a stagnant culture (Fig. 2c) but could not be readily detected in the L-form. Several of the L-form phosphoproteins were characterized further.

\section{$80 \mathrm{kDa}$ - TypA}

The $80 \mathrm{kDa}$ phosphoprotein (protein M, Fig. 2a) corresponds to TypA (Tyrosine Protein A), the product of the 0591 gene (Freestone et al., 1995, 1998), on the 


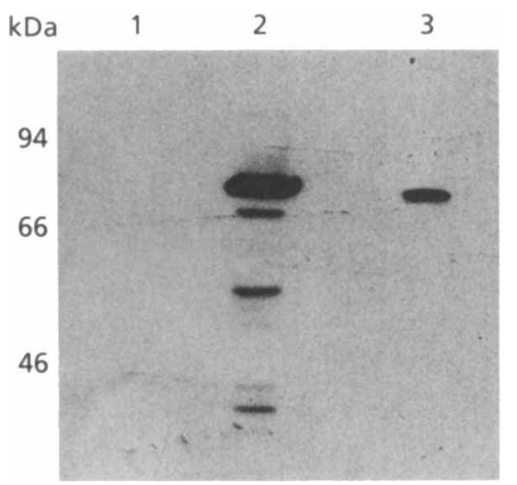

Fig. 3. Cross-reaction with anti-phosphotyrosine antibodies. In vivo phosphorylation of TypA in total cell extracts of $E$. coli probed with anti-phosphotyrosine antibodies. Lanes: 1, K-12 strain 3301; 2, MAR001; 3, L-form NC-7.

basis of molecular mass, cross-reactivity with antibodies to TypA, stability to acid and base hydrolysis, elution characteristics and stimulation of phosphorylation by divalent metal ions and hydrophobic compounds (Fig. 1, lanes $2-6$, and data not shown). TypA is one of the very few proteins in E. coli phosphorylated on tyrosine residues (Freestone et al., 1995) and neither we nor others have observed its phosphorylation in laboratory strains under a wide range of conditions including anaerobic growth (Freestone et al., 1998; Farris et al., 1998). Probing with anti-phosphotyrosine antibodies confirmed that TypA is phosphorylated on tyrosine in the $\mathrm{L}$-form in vivo but not in the parental or other $\mathrm{K}-12$ strains (Fig. 3).

\section{$19 \mathrm{kDa}-\mathrm{Dps}$}

A particularly labile kinase activity responsible for phosphorylation of a $19 \mathrm{kDa}$ protein - but distinct from it on the basis of elution characteristics - was observed in a fraction eluted by $150 \mathrm{mM} \mathrm{NaCl}$ (protein D, Fig. 2a). This activity required only magnesium: no stimulation was observed with calcium, manganese or lipid, while zinc was slightly inhibitory (data not shown). Phosphorylation of the $19 \mathrm{kDa}$ protein was stable to acid but not base hydrolysis consistent with phosphorylation on serine or threonine residues; only a small proportion of the protein was phosphorylated in our in vitro assay (data not shown). N-terminal sequencing of this protein gave MSTAKLVKSKA, which corresponds to the first 11 amino acids of the Dps protein (Almiron et al., 1992). Phosphorylation of Dps was not observed under either of the conditions in which the parental strain was grown (Fig. 2b, c).

\section{$14 \mathrm{kDa}-\mathrm{YfiD}$}

The kinase activity responsible for the phosphorylation of a $14 \mathrm{kDa}$ protein (protein $\mathrm{Y}$ in Fig. $2 \mathrm{a}$ ) in a fraction adjacent to that containing the Dps protein was also

\begin{tabular}{|c|c|c|}
\hline $\begin{array}{ll}\text { YfiD: } & \text { MITGIQITKA } \\
\text { ecpfl: } & \text { ANPMHGRDQK }\end{array}$ & $\begin{array}{l}\text { ANDDLINSFW } \\
\text { GAVASLTSVA }\end{array}$ & $\begin{array}{l}\text { LIDSEKGEAR } \\
\text { KIPFAYAKDG }\end{array}$ \\
\hline $\begin{array}{ll}\text { YfiD: } & \text { CIVAKAGYAE } \\
\text { ecplf: } & \text { ISYTFSIVPN }\end{array}$ & $\begin{array}{l}\text { DEVVAVSKIG } \\
\text { ALGKDDEVRK }\end{array}$ & $\begin{array}{l}\text { DIEYREVPVE } \\
\text { TNLAGLMDGY }\end{array}$ \\
\hline $\begin{array}{ll}\text { YfiD: } & \text { VKPEVRVEGG } \\
\text { ecpfl: } & \text { FHHEASIEGG }\end{array}$ & $\begin{array}{l}\text { QHLNVNVLRR } \\
\text { QHLWVMVMNR }\end{array}$ & $\begin{array}{l}\text { ETLEDAVKHP } \\
\text { EMLLDAMENP }\end{array}$ \\
\hline $\begin{array}{ll}\text { YfiD: } & \text { EKYPQLTIRV } \\
\text { ecpfi: } & \text { EKYPQLTIRV }\end{array}$ & $\begin{array}{l}\text { SGYAVRFNSL } \\
\text { SGYAVRFNSL }\end{array}$ & $\begin{array}{l}\text { TPEQQRDVIA } \\
\text { TKEQQQDVIT }\end{array}$ \\
\hline $\begin{array}{ll}\text { YfiD: } & \text { RTFTESL } \\
\text { ecpfl: } & \text { RTFTQSM }\end{array}$ & & \\
\hline
\end{tabular}

Fig. 4. Comparison of the entire YfiD sequence with residues 633-759 of pyruvate formate-lyase. Identical residues are shown in bold.

very labile (data not shown). Phosphorylation of the $14 \mathrm{kDa}$ protein was only dependent upon magnesium; this phosphorylation was neither stimulated by manganese, calcium and lipid nor inhibited by zinc (data not shown). The phosphoresidue(s) of this protein was unstable to acid hydrolysis and partially stable to hot alkaline hydrolysis consistent with phosphorylation on histidine or lysine residues (data not shown). $\mathrm{N}$-terminal sequencing of the $14 \mathrm{kDa}$ phosphoprotein gave MTITGIQITKA. This matches nine out of the first ten residues, MITGIQITKA (protein accession no. p33633.swiss and gene no. yfid_ecoli), of a 127-residue product of predicted molecular mass $14.3 \mathrm{kDa}$ in the $3^{\prime}$ ung region at $56 \mathrm{~min}$, which encodes uracil DNA glycosylase (Green \& Baldwin, 1997). The $14 \mathrm{kDa}$ protein showed a $95 \%$ homology over its entire length to the possible product of a gene of unknown function in Serratia liquefaciens and a $77 \%$ homology over 64 residues (positions 65-129) to the C-terminus of $E$. coli pyruvate formate-lyase (Rodel et al., 1988), which is encoded by a gene in the $20 \mathrm{~min}$ region of the genome (Fig. 4). Essentially the same region (positions 41-109) has a $68 \%$ homology over 68 residues to a sequence in bacteriophage T5 located in a region containing a tRNA cluster (data not shown). Although the $14 \mathrm{kDa}$ product of $y f i D$ was one of the most abundant proteins in extracts of the L-form as judged by Coomassie blue staining, only a small proportion of the protein was phosphorylated in our in vitro assay (data not shown). Under native conditions, YfiD exists as a particularly heat-stable, monomeric protein which, when separated by two-dimensional electrophoresis, makes at least two isoforms (data not shown). Neither YfiD protein nor Y fiD phosphorylation was detected in the L-form parent when growing aerobically (Fig. $2 b$ ) and, although YfiD can be produced in cells that are grown anaerobically (Green \& Baldwin, 1997), phosphorylation of YfiD in the L-form parent could not be detected following growth as a stagnant culture (Fig. 2c). 


\section{DISCUSSION}

Studies of protein phosphorylation in L-forms may benefit from the ease and rapidity of extracting proteins, which helps preserve labile activities, and the nature of L-form growth, which may up-regulate these activities. Although in vitro phosphorylation studies are subject to a number of artefacts, most of the proteins we have identified as phosphorylated in vitro are also phosphorylated in vivo (Freestone et al., 1995, 1997, 1998; Sweeney et al., 1995). Phosphorylation of TypA on tyrosine is intriguing. Although phosphorylation on tyrosine in prokaryotes has been subject to controversy (Cortay et al., 1986b; Foster et al., 1989), phosphorylation on this residue has now been observed in several species of bacteria (for example, Duclos et al., 1996; Freestone et al., 1995; Ostrovsky \& Maloy, 1995; Smith et al., 1997). TypA, encoded by the 0591 sequence and having a significant homology to ribosome-binding elongation factors G (Plunkett et al., 1993), is phosphorylated in vitro and in vivo on tyrosine residue(s) in clinical isolates of $E$. coli but not in laboratory strains (Freestone $e$ t al., 1995, 1998; Farris et al., 1998). TypA, also known as BipA, has recently been implicated in the formation of actin-rich pedestals in epithelial cells during enteropathogenic $E$. coli infections and in resistance to the cationic host defence peptide BPI (Farris et al., 1998). The BipA homologue in Salmonella typhimurium is considered a global regulator involved in bacterial survival during the invasion of the host $(\mathrm{Q} i$ et al., 1995). In E. coli, TypA is an autophosphorylating protein that affects the phosphorylation of UspA, a protein that is induced by a variety of stresses and that determines bacterial survival during growth arrest (Freestone et al., 1997). A role for TypA as a global regulator would be consistent with our findings that in a typA mutant the synthesis and/or post-translational modification of 12 other proteins are affected in exponential phase and still more in stationary phase (Freestone et al., 1998). It is far from clear how L-forms maintain their structural integrity and it is conceivable that TypA promotes both rearrangements of the cytoskeleton in host cells and reinforcement of an 'enzoskeleton' in L-forms (Norris et al., 1996). The fact that phosphorylation of TypA occurs in the NC-7 Lform, which is derived from a K-12 laboratory strain, means that the factors responsible for stimulating its phosphorylation might in principle be identified by comparative studies of the L-form, its parental strain and clinical isolates.

Phosphorylation of the Dps protein was observed. This protein is produced in starvation conditions to protect DNA against oxidative damage (Almiron et al., 1992). The characteristics of the stability of the phospholabelling of Dps to acid and base hydrolysis are indicative of phosphorylation on serine or threonine residues. When purified, Dps forms highly ordered arrays in the presence of DNA (Almiron et al., 1992) and is a principal component of 'actomyosin' preparations of E. coli (Foster, 1993). The reason for the phosphorylation of Dps in L-forms is unclear since this phosphorylation was not detected in the parental strain when grown in similar conditions (including growth as a stagnant culture) or, indeed, in any other conditions; it is conceivable that Dps contributes to the structural stability of the L-forms and Dps phosphorylation is part of the regulation of the putative enzoskeleton (Norris $e t$ al., 1996). The kinase activity responsible for Dps phosphorylation has not been reported previously. This may be because it is both very labile, requiring the rapid extraction that L-forms permit, and quite elusive, being absent under many growth conditions.

A similarly labile phosphorylation was also observed of the $14 \mathrm{kDa}$ product of the $y f \mathrm{D}$ gene at $56 \mathrm{~min}$ on the genome. The speculation that the same kinase activity is responsible for the phosphorylation of both YfiD and Dps would be consistent with the distribution of these proteins and their phosphorylated isoforms. However, zinc inhibits Dps but not YfiD phosphorylation and this argues against a common kinase. The characteristics of the stability of the phosphoresidue(s) of the proteins to acid and base hydrolysis are also different, with those of YfiD indicative of phosphorylation on either histidine or lysine residues (or both). In vivo, YfiD exists as two isoforms consistent with a substantial proportion of the protein being modified by, for example, phosphorylation. $y f D$ has a class 1 promoter with FNR boxes to which FNR, the anaerobic transcription regulator of $E$. coli, binds (Green \& Baldwin, 1997). yfiD is induced by the synthesis in anaerobically growing (but not aerobically growing) E. coli of HlyX, a homologue of FNR found in Actinobacillus pleuropneumoniae (Green \& Baldwin, 1997). YfiD is one of four proteins in E. coli with homology to pyruvate formate-lyase (G. Sawers \& J. Knappe, personal communication). In particular, YfiD has a remarkable homology to the C-terminus of pyruvate formate-lyase which plays a role in the catalysis by pyruvate formate-lyase of the non-oxidative conversion of pyruvate to acetyl-CoA in anaerobically growing E. coli (Rodel et al., 1988). A free radical, assigned to glycine-734 in the C-terminus of pyruvate formate-lyase (Wagner et al., 1992), is involved in the generation of the catalytically active thiyl radical that initiates homolytic cleavage of the pyruvate $\mathrm{C}-\mathrm{C}$ bond (Knappe et al., 1993). The equivalent of glycine-734 is conserved in YfiD (Fig. 4). A related function for YfiD and its phosphorylation in metabolism is conceivable. However, this would not explain why Yfid is one of the most abundant proteins in the $\mathrm{L}$-form under conditions (nearly $2 \mathrm{~d}$ growth without agitation) in which it is undetectable in the parental strain.

Phosphorylation of a $40 \mathrm{kDa}$ protein was stimulated by addition of calcium to total cell extracts. However, a phosphorylation with similar characteristics was not observed in fractions. One obvious explanation for this is that kinase and substrate are separated by anionexchange chromatography. In view of the potential importance of calcium-stimulated kinase activities in the control of cellular structure and the cell cycle (Norris, 1989; Yu \& Margolin, 1997), the identification of this phosphoprotein must be a priority for future research. 
Although L-forms have been shown to prevent the development of disease in plants due to pathogenic attack (Waterhouse et al., 1996), they remain a relatively neglected tool for studies of fundamental bacterial processes. These studies include those in vitro where labile enzymes must be purified and those in vivo where the outer membrane and peptidoglycan sacculus interfere with export, import or the action of various compounds (Klessen et al., 1989), and, as we and others have argued (for example, Gumpert, 1992; Waterhouse et al., 1994), they may also include intracellular structure, signal transduction, cell cycle regulation and even the origin of life. Indeed, the ability of L-forms to survive and grow suggests that these wall-less bacteria manage to co-opt enzymic pathways and the force-generating processes of transcription and translation to maintain their structural integrity as perhaps protocells did early in evolution (Norris et al., 1998).

\section{ACKNOWLEDGEMENTS}

We thank Dick D'Ari, Mick Pocklington, Richard Herrmann, Gary Sawers, Joachim Knappe and Alain Cozzone for helpful discussions. We also thank the EU (CT91-0713 and CT920010), the BBSRC and Cell Cycle Research for support.

\section{REFERENCES}

Almiron, M., Link, A. J., Furlong, D. \& Kolter, R. (1992). A novel DNA-binding protein with regulatory and protective roles in starved Escherichia coli. Genes Dev 6, 2646-2654.

Baldini, M. M., Kaper, J. B., Levine, M. M., Candy, D. C. A. \& Moon, H.W. (1983). Plasmid-mediated adhesion of enteropathogenic Escherichia coli. J Pediatr Gastroenterol Nutr 2, 534-538.

Bi, E. \& Lutkenhaus, J. (1991). FtsZ ring structure associated with division in Escherichia coli. Nature 354, 161-164.

Cegielska, A. \& Georgopoulos, C. (1989). Functional domains of the Escherichia coli dnaK heat shock protein as revealed by mutational analysis. J Biol Chem 264, 21122-21130.

Cortay, J.-C., Rieul, C., Duclos, B. \& Cozzone, A. J. (1986a). Characterization of the phosphoproteins of Escherichia coli by electrophoretic analysis. Eur J Biochem 159, 227-237.

Cortay, J. C., Duclos, B. \& Cozzone, A. J. (1986b). Phosphorylation of an Escherichia coli protein at tyrosine. J Biol Chem 187, 305-308.

Duclos, B., Grangeasse, C., Vaganay, E., Riberty, M. \& Cozzone, A. J. (1996). Autophosphorylation of a bacterial protein at tyrosine. J Mol Biol 259, 891-895.

Farris, M., Grant, A., Richardson, T. B. \& O'Connor, C. D. (1998). BipA: a tyrosine-phosphorylated GTPase that mediates interactions between enteropathogenic Escherichia coli (EPEC) and epithelial cells. Mol Microbiol 28, 265-279.

Foster, R., Thorner, J. \& Martin, G. S. (1989). Nucleotidylation, not phosphorylation, is the major source of the phosphotyrosine detected in enteric bacteria. J Bacteriol 171, 272-279.

Foster, S. J. (1993). Purification and characterization of an 'actomyosin' complex from Escherichia coli W3110. FEMS Microbiol Lett 295, 295-298.

Freestone, P., Grant, S., Toth, I. \& Norris, V. (1995). Identification of phosphoproteins in Escherichia coli. Mol Microbiol 15, 573-580.
Freestone, P., Nyström, T., Trinei, M. \& Norris, V. (1997). The Universal Stress Protein, UspA, of Escherichia coli is phosphorylated in response to stasis. $J$ Mol Biol 274, 318-324.

Freestone, P., Trinei, M., Clarke, S. C., Nyström, T. \& Norris, V. (1998). Tyrosine phosphorylation in Escherichia coli. J Mol Biol 279, 1045-1051.

Green, J. \& Baldwin, M. L. (1997). HlyX, the FNR homologue of Actinobacillus pleuropneumoniae, is a $[4 \mathrm{Fe}-4 \mathrm{~S}]$-containing oxygen-responsive transcription regulator that anaerobically activates FNR-dependent class I promoters via an enhanced AR1 contact. Mol Microbiol 24, 593-605.

Guerrero-Barrera, A. L., Garcia-Cuellar, C. M., Villalba, J. D., Segura-Nieto, M., Gomez-Lojero, C., Reyes, M. E., Hernandez, J. M., Garcia, R. M. \& de la Garza, M. (1996). Actin-related proteins in Anabaena spp. and Escherichia coli. Microbiology 142, 1133-1140.

Gumpert, J. (1992). Cellular growth without a murein sacculus the nucleoid-associated compartmentation concept. In Bacterial Growth and Lysis. Metabolism and Structure of the Bacterial Sacculus, pp. 453-463. Edited by M. A. de Pedro, J.-V. Holtje \& W. Loffelhardt. New York \& London: Plenum.

Ingber, D. E. (1993). The riddle of morphogenesis: a question of solution chemistry or molecular cell engineering? Cell 75, 1249-1252.

Kennelly, P. J. \& Potts, M. (1996). Fancy meeting you here! A fresh look at 'prokaryotic' protein phosphorylation. J Bacteriol 178, 4759-4764.

Klessen, C., Schmidt, K.-H., Gumpert, J., Grosse, H.-H. \& Malke, H. (1989). Complete secretion of activable bovine prochymosin by genetically engineered $\mathrm{L}$ forms of Proteus mirabilis. Appl Environ Microbiol 55, 1009-1015.

Knappe, J., Elbert, S., Frey, M. \& Wagner, A. F. (1993). Pyruvate formate-lyase mechanism involving the protein-based glycyl radical. Biochem Soc Trans 21, 731-734.

Lederberg, J. \& St Clair, J. (1958). Protoplasts and L-type growth of Escherichia coli. J Bacteriol 75, 143-160.

Lippmann, C., Lindschau, C., Vijgenboom, E., Schroder, W., Bosch, L. \& Erdmann, V. A. (1993). Prokaryotic elongation factor $\mathrm{Tu}$ is phosphorylated in vivo. J Biol Chem 268, 601-607.

Ma, X., Ehrhardt, D. W. \& Margolin, W. (1996). Colocalization of cell division proteins FtsZ and FtsA to cytoskeletal structures in living Escherichia coli cells by using green fluorescent protein. Proc Natl Acad Sci USA 93, 12998-13003.

McCarthy, J. S. \& Walker, G. C. (1991). DnaK as a thermometer: threonine-199 is site of autophosphorylation and is critical for ATPase activity. Proc Natl Acad Sci USA 88, 9513-9517.

Mendes, P., Kell, D. B. \& Welch, G. R. (1995). Metabolic channelling in organized enzyme systems: experiments and models. Adv Mol Cell Biol 11, 1-19.

Norris, V. (1989). A calcium flux at the termination of replication triggers cell division in E. coli. Cell Calcium 10, 511-517.

Norris, V., Baldwin, T. J., Sweeney, S. T., Williams, P. H. \& Leach, K. L. (1991). A protein kinase C-like activity in Escherichia coli. Mol Microbiol 5, 2977-2981.

Norris, V., Turnock, G. \& Sigee, D. (1996). The Escherichia coli enzoskeleton. Mol Microbiol 19, 197-204.

Norris, V., Onoda, T., Pollaert, H. \& Grehan, G. (1998). The mechanical origins of life. BioSystems (in press).

Onoda, T. \& Oshima, A. (1988). Effects of $\mathrm{Ca}^{2+}$ and a protonophore on growth of an Escherichia coli L-form. J Gen Microbiol 134, 3071-3077. 
Onoda, T., Oshima, A., Nakano, S. \& Matsuno, A. (1987). Morphology, growth and reversion in a stable L-form of Escherichia coli K12. J Gen Microbiol 133, 527-534.

Onoda, T., Oshima, A., Fukunaga, N. \& Nakatani, A. (1992). Effect of $\mathrm{Ca}^{2+}$ and $\mathrm{K}^{+}$on the intracellular $\mathrm{pH}$ of an Escherichia coli $\mathrm{L}-$ form. J Gen Microbiol 138, 1265-1270.

Ostrovsky, P. C. \& Maloy, S. (1995). Protein phosphorylation on serine, threonine, and tyrosine residues modulates membraneprotein interactions and transcriptional regulation in Salmonella typhimurium. Genes Dev 9, 2034-2041.

Paton, A. M. (1987). L-forms: evolution or revolution? J Appl Bacteriol 63, 365-371.

Plunkett, G., III, Burland, V., Daniels, D. L. \& Blattner, F. R. (1993). DNA sequence of the region from 87.2 to 89.2 minutes. Nucleic Acids Res 21, 3391-3398.

Qi, S.-Y., Li, Y., Szyroki, A., Giles, I. G., Moir, A. \& O'Connor, C. D. (1995). Salmonella typhimurium responses to a bactericidal protein from human neutrophils. Mol Microbiol 17, 523-531.

Rodel, W., Plaga, W., Frank, R. \& Knappe, J. (1988). Primary structures of Escherichia coli pyruvate formate-lyase and pyruvate-formate-lyase-activating enzyme deduced from the DNA nucleotide sequences. Eur J Biochem 177, 153-158.

Saier, M. H., Jr (1993). Introduction : protein phosphorylation and signal transduction in bacteria. $J$ Cell Biochem 51, 1-6.

Sanchez, M., Valencia, A., Ferrandiz, M.-J., Sandler, C. \& Vicente, M. (1994). Correlation between the structure and biochemical activities of FtsA, an essential cell division protein of the actin family. EMBO J 13, 4919-4925.

Sherman, M. Y. \& Goldberg, A. L. (1993). Heat shock of Escherichia coli increases binding of $\mathrm{dnaK}$ (the hsp 70 homolog) to polypeptides by promoting its phosphorylation. Proc Natl Acad Sci USA 90, 8648-8652.
Smith, S. C., Kennelly, P. J. \& Potts, M. (1997). Protein-tyrosine phosphorylation in the Archaea.J Bacteriol 179, 2418-2420.

Sood, P., Lerner, C. G., Shimamoto, T., Lu, Q. \& Inouye, M. (1994). Characterization of the autophosphorylation of Era, an essential Escherichia coli GTPase. Mol Microbiol 12, 201-208.

Srere, P. A. (1987). Complexes of sequential metabolic enzymes. Annu Rev Biochem 56, 89-124.

Sweeney, S. T., Freestone, P. \& Norris, V. (1995). Identification of novel phosphoproteins in Escherichia coli using the gene-protein database. FEMS Microbiol Lett 127, 133-138.

Wagner, A. F. V., Frey, M., Neugebauer, F. A., Schäfer, W. \& Knappe, J. (1992). The free radical in pyruvate formate-lyase is located on glycine-734. Proc Natl Acad Sci USA 89, 996-1000.

Waterhouse, R. N., Allan, E. J., Amijee, F., Undrill, V. J. \& Glover, L. A. (1994). An investigation of enumeration and DNA partitioning in Bacillus subtilis L-form bacteria. J Appl Biol 77, 497-503.

Waterhouse, R. N., Buhariwalla, H., Bourn, D., Rattray, E. J. \& Glover, L. A. (1996). CCD detection of lux-marked Pseudomonas syringae pv. phaseolicola L-forms associated with Chinese cabbage and the resulting disease protection against Xanthomonas campestris. Lett Appl Biol 22, 262-266.

Weiser, J., Mikulik, K., Zizka, Z., Stastna, J., Janda, I. \& Jiranova, A. (1982). Isolation and characterization of Streptomyces aureofaciens protein-synthesis elongation factor $\mathrm{Tu}$ in an aggregated state. Eur J Biochem 129, 127-132.

Yu, X.-C. \& Margolin, W. (1997). $\mathrm{Ca}^{2+}$-mediated GTP-dependent assembly of bacterial cell division protein FtsZ into asters and polymer networks in vitro. EMBO J 16, 5455-5463.

Received 3 August 1998; revised 1 September 1998; accepted 4 September 1998. 